\title{
The Effect of KAATSU Resistance Exercises on some Variables Physical and functional skills of Boxers
}

\author{
Dr Mohamed Zakaria Baldam \\ Lecturer, Department of Combat Sports - Faculty of Physical Education - Tanta University
}

\section{Introduction and research problem}

Excellence and universality in the sport of higher levels is an objective sought by every athlete and every country. The sports field in general and high level sports in particular have witnessed a rapid and wide-ranging scientific development as a result of the use of modern methods and techniques that contribute to improving the level of sport in all sports activities.

The physical natural adaptation of the muscles depends on the quality of the correlation and harmony of the variables and the work protocol with resistance training (intensity of training - volume of training - frequency - and hospitalization) and leads Training at high doses to muscle hypertrophy, improves performance. But this type of exercise may increase the level of physical load and muscle fatigue. Thus, it is useful to develop safer and more effective methods to promote muscle hypertrophy without any negative effects $(37: 16)$ (1465: 26.)

The amount of adaptation gained from the training is proportional to the motivation and the amount of effort made, and although it depends on individual experience in training and fitness level, for example the intensity of training that exceeds $65 \%$ of the player's maximum capacity is the minimum acceptable The positive effect we want to increase muscle inflation and achieve the required muscle strength (100:28) (55:31)

The majority of the results agreed that the intensity of the exercise is less than (65\%). There is rarely an increase in the perimeter and mass of the muscles. 3) Times a week is an important factor in increasing the level of concentration of growth hormone, which is the basis of muscle growth and strength (24:19) (88:32).

Shinohara (2002) and Takashi Takashi (2000) agree that exercise by restricting venous blood flow significantly contributes to increased muscle inflation and increased muscle strength (77:29) (84:31.)

Many scientists have agreed that the association of low-intensity physical loads (20$50 \%$ ) in resistance training and restriction of venous blood flow (ACT) to active muscles may be an easier alternative to achieving the goal of these exercises, Conventional methods are used to increase the speed of muscle and muscle size, but they may not be as effective on hormones as high loads (12:23)

Abe, T, Abe (2004) indicates that high levels of strength using training exercises for more than $(80 \%)$ require relatively long rest periods between the training modules, according to the high performance load, mechanical pressure and maximum muscle damage, While the low loads do not affect the intensity (50\%) and the effect does not occur (207: 16)

In addition to the effects of training on muscle size and strength, it helps to achieve metabolic adjustment in skeletal muscle.

It represents the metabolic responses to the blood feeding of the muscles. 7 The KAATSU exercises also help to increase muscle stock of glycogen and produce a large amount of ATP during rest Muscle

(138: 27.) 
Resistance and strength exercises cause a high level of blood flow to active muscles starting from the first muscle contraction, which depends on the persistence and high level of physical activity (18: 8)

Gabel (2009) agrees that muscle strength is one of the key ingredients for success in athletic performance. The best boxer has some genes to develop muscular strength and muscular endurance training has many benefits, including muscular construction of the boxer's body and injury prevention. 41:15)

The muscle strength group (force strength - muscle capacity - explosive power) is the biggest factor in the success of the boxer as reinforced by one of the pioneers of sports education, when Mecloy Mkloi proved that power is the most important elements of fitness in the motor performance of boxers, Funders are working to develop their strength to fit the technical requirements of the match so that they can perform punches strongly during performance (1: 85) (47:5)

Abdul Fattah Fathi (2005) points out the importance of strength for a boxer and boxer who has high physical abilities characterized by good skill performance and excellent performance, and physical exercises together are the main pres of developing sports formation during both preparation and pre-competition periods $(4: 15)$

The researcher noted that some boxing trainers do not have the know-how in the training of the KAATSU, which helps to develop muscle strength, which is the main factor and decisive in boxing sport, which prompted the researcher to do this study to recognize the impact of resistance exercises KAATSU style on some physical and functional variables of the new boxing.

\section{Research goal}

The aim of this research is to identify the effect of KAATSU resistance training on some of the physical and functional variables of boxing beginners.

\section{Research hypotheses}

-There are statistically significant differences between the averages of the pre and post measurements at the level of some functional variables in boxers experimental research group.

-There are statistically significant differences between the averages of the pre and post measurements at the level of some functional variables in the adult boxers control group.

-There were statistically significant differences between the two dimensions of the two dimensional measurements in the experimental and control groups at the level of some functional variables among the adult boxers and for the experimental research group.

\section{Some terms in the search}

\section{-KAATSU}

Is the use of sports exercises in a manner that restricts venous blood by tying the belts to varying degrees on the working muscles during the training performance (41:7)

\section{Research plan and procedures Approach}

The researcher used the experimental method for two groups, one experimental and the other control, in order to suit the nature of the research and to achieve the goals and hypotheses.

\section{The research sample}

The researcher selected the research sample by pres of the intentional way (16) boxers of Tanta Sports Club boxers registered with the Egyptian Boxing Federation and divided into 
two groups of each (6) boxers, one experimental and the other an officer in addition to (4) boxers to conduct the exploratory study

Table (1) Characteristics of sample search for boxers $N=16$

\begin{tabular}{c|l|l|l|l|l|c}
\hline \hline Serial & Variables & Unit & SMA & $\begin{array}{l}\text { Standard } \\
\text { Deviation }\end{array}$ & SMA & $\begin{array}{l}\text { Standard } \\
\text { Deviation }\end{array}$ \\
\hline \hline 1 & Height & Cm & 173.650 & 6.2 & 176.25 & 0.422 \\
\hline 2 & Weight & Kg & 75.40 & 2.15 & 76.25 & 0.368 \\
\hline 3 & Age & Month & 21.88 & 0.25 & 21.50 & 0.147 \\
\hline 4 & The training age & Year & 10.60 & 1.10 & 10.50 & 0.041 \\
\hline \hline
\end{tabular}

Table (1) indicates that the torsion coefficients of the variables of height, weight, age and training age of the individuals in the study sample are limited to $( \pm 3)$, indicating that the vocabulary is distributed in a symmetrical manner

Table (2) The parity of the experimental and control groups in the level some functional variables $\mathrm{N}=12$

\begin{tabular}{|c|c|c|c|c|c|c|}
\hline \multirow[b]{2}{*}{ Variables } & \multirow{2}{*}{$\begin{array}{l}\text { Measuring } \\
\text { Unit }\end{array}$} & \multicolumn{2}{|c|}{ Control group } & \multicolumn{2}{|c|}{ The experimental group } & \multirow{2}{*}{$\begin{array}{c}\text { "T" } \\
\text { valv } \\
\text { e }\end{array}$} \\
\hline & & SMA & $\begin{array}{l}\text { Standard } \\
\text { Deviation }\end{array}$ & SMA & $\begin{array}{l}\text { Standard } \\
\text { Deviation }\end{array}$ & \\
\hline $\begin{array}{l}\text { Ability of the legs } \\
\text { muscles }\end{array}$ & $\mathrm{Cm}$ & 33.25 & 0.96 & 33.20 & 0.75 & 0.69 \\
\hline Strength of leg muscles & $\mathrm{Kg}$ & 55.21 & 0.21 & 55.25 & 0.63 & 0.32 \\
\hline $\begin{array}{c}\text { Abdominal muscle } \\
\text { capacity }\end{array}$ & No & 18.11 & 0.17 & 18.20 & 0.21 & 0.17 \\
\hline $\begin{array}{c}\text { Strength of abdominal } \\
\text { muscles }\end{array}$ & $\mathrm{Kg}$ & 38.26 & 0.52 & 38.51 & 0.52 & 0.52 \\
\hline $\begin{array}{c}\text { Strength of back } \\
\text { muscles }\end{array}$ & $\mathrm{Kg}$ & 52.32 & 0.36 & 52.50 & 0.36 & 0.36 \\
\hline Muscle capacity Arms & No & 15.32 & 0.887 & 15.52 & 0.25 & 0.21 \\
\hline $\begin{array}{l}\text { Strength of arm } \\
\text { muscles }\end{array}$ & M & 5.50 & 0.65 & 5.51 & 0.98 & 0.74 \\
\hline $\begin{array}{l}\text { The strength of the right } \\
\text { fist }\end{array}$ & $\mathrm{Kg}$ & 31.02 & 0.15 & 31.09 & 0.32 & 0.28 \\
\hline $\begin{array}{l}\text { The strength of the left } \\
\text { fist }\end{array}$ & $\mathrm{Kg}$ & 28.80 & 0.36 & 28.95 & 0.28 & 0.32 \\
\hline Circumference of arms & $\mathrm{Cm}$ & 20.20 & 0.32 & 20.23 & 0.41 & 0.11 \\
\hline $\begin{array}{c}\text { Circumference of the } \\
\text { legs }\end{array}$ & $\mathrm{Cm}$ & 27.25 & 0.14 & 27.22 & 0.23 & 0.69 \\
\hline
\end{tabular}

Value (T) at significance level $(0.05)=1.85$

Table (2) shows that there are no statistically significant differences between the averages of pre measurements in the experimental and control groups. The calculated value $(t)$ is less than the tabular value, indicating the equivalence of the two research groups in the variables under consideration.

\section{Search tools}

1-Data registration form 
2-Measurements under study (using the magnetometer force of the fist and dynamometer for the muscles of the back and legs - the muscle circumference using a tape measure included to measure the muscle circumference - electronic blood pressure to measure the rate of systolic and diastolic pressure and heart rate)

3-Tools (boxing ring - figure)

4-Devices (dynamometer - manometer - video camera - multiple belts)

Tests and measurements used in research

1-Test slant to measure the muscular endurance of the arms.

2-Measuring the strength of the muscles of the back and legs using dynamometer.

3-Measuring the strength of the fist using a manometer.

4-Measuring the perimeter of the muscles using a tape measure included.

Design of venous blood flow restriction:

The blood pressure of the forearm was measured 15 minutes before the test. The end of the arm muscle in the distance between the biceps humerus and the inferior side of the anterior dorsal muscle was determined by elastic belts under the clothing and directly on the muscles. (120 mmHg) of systolic blood pressure the same procedures were performed for the femoral muscle and leg muscles. A gradual increase in the height of the load is performed by increasing the pressure of the belts on the (10) $\mathrm{mmHg}$ to be reached (160) $\mathrm{mmHg}$ at the end of the program.

\section{Training program:}

The program was applied to all boxers, ranging between $(65-85 \%)$ of the maximum training intensity for each measured word relative to the heart rate using the Polar clock, by repeating the punches for (30) w with different repetitions, at a rate of (3) Both groups applied the same program and used external weights with the difference that the experimental group performed by restricting venous blood flow. While the control group did the same exercise without restricting venous blood flow, the training program was designed 3 times a week for 10 consecutive weeks for both groups.

View and discuss the results

Table (3) Indication of differences and improvement ratios between pre and post measurements Experimental research sample in tests of physical and functional variables $n=6$

\begin{tabular}{c|c|c|c|c|c|c|c|c|c}
\hline \hline \multirow{2}{*}{ Variables } & \multirow{2}{*}{$\begin{array}{c}\text { Measuring } \\
\text { Unit }\end{array}$} & \multicolumn{2}{|c|}{$\begin{array}{c}\text { Pre } \\
\text { measuring }\end{array}$} & \multicolumn{2}{c|}{$\begin{array}{c}\text { Post } \\
\text { measuring }\end{array}$} & $\begin{array}{c}\text { Difference } \\
\text { between } \\
\text { the two } \\
\text { averages }\end{array}$ & $\begin{array}{c}\text { Improvement } \\
\text { rate }\end{array}$ & $\begin{array}{c}\text { Value (T) } \\
\text { Calculated }\end{array}$ & $\begin{array}{c}\text { Level of } \\
\text { significance }\end{array}$ \\
\hline \hline $\begin{array}{c}\text { Ability of the } \\
\text { legs muscles }\end{array}$ & $\mathrm{Cm}$ & 33.25 & 0.96 & 36.52 & 0.21 & 3.27 & 9.83 & 3.98 & Indicated \\
\hline $\begin{array}{c}\text { Strength of } \\
\text { leg muscles }\end{array}$ & $\mathrm{Kg}$ & 55.21 & 0.21 & 67.21 & 0.17 & 12.00 & 17.85 & 3.25 & Indicated \\
\hline $\begin{array}{c}\text { Abdominal } \\
\text { muscle } \\
\text { capacity }\end{array}$ & $\mathrm{No}$ & 18.11 & 0.17 & 22.52 & 0.36 & 4.41 & 19.58 & 3.14 & Indicated \\
\hline $\begin{array}{c}\text { Strength of } \\
\text { abdominal } \\
\text { muscles }\end{array}$ & $\mathrm{Kg}$ & 38.26 & 0.52 & 45.32 & 0.52 & 7.06 & 15.57 & 3.65 & Indicated \\
\hline $\begin{array}{c}\text { Strength of } \\
\text { back muscles }\end{array}$ & $\mathrm{Kg}$ & 52.32 & 0.36 & 64.20 & 0.32 & 11.88 & 18.50 & 3.28 & Indicated \\
\hline
\end{tabular}




\begin{tabular}{c|c|c|c|c|c|c|c|c|c}
\hline $\begin{array}{c}\text { Muscle } \\
\text { capacity } \\
\text { Arms }\end{array}$ & $\mathrm{No}$ & 15.32 & 0.887 & 22.26 & 0.14 & 6.94 & 31.17 & 3.54 & Indicated \\
\hline $\begin{array}{c}\text { Strength of } \\
\text { arm muscles }\end{array}$ & $\mathrm{M}$ & 5.50 & 0.65 & 8.21 & 0.52 & 2.71 & 33.00 & 3.21 & Indicated \\
\hline $\begin{array}{c}\text { The strength } \\
\text { of the right } \\
\text { fist }\end{array}$ & $\mathrm{Kg}$ & 31.02 & 0.15 & 38.21 & 0.28 & 7.19 & 18.81 & 3.85 & Indicated \\
\hline $\begin{array}{c}\text { The strength } \\
\text { of the left fist }\end{array}$ & $\mathrm{Kg}$ & 28.80 & 0.36 & 36.10 & 0.32 & 7.30 & 20.22 & 3.15 & Indicated \\
\hline $\begin{array}{c}\text { Circumference } \\
\text { of arms }\end{array}$ & $\mathrm{Cm}$ & 19.65 & 0.36 & 22.32 & 0.32 & 2.67 & $13.58 \%$ & 3.58 & Indicated \\
\hline $\begin{array}{c}\text { Circumference } \\
\text { of the legs }\end{array}$ & $\mathrm{Cm}$ & 28.33 & 0.58 & 31.58 & 0.14 & 3.45 & $11.47 \%$ & 3.69 & Indicated \\
\hline \hline
\end{tabular}

Tabular value at a significant level of 0.05 and freedom degrees $9=2.26$

Table (3) shows statistically significant differences between the pre and post measurements of the experimental group in the functional variables tests for the benefit of the telemetry. The value of $(t)$ was greater than the tabular value at the significance level $(0.05)$

Table (4) Indication of differences and improvement ratios between pre and post measurements The control sample in tests of functional variables $n=6$

\begin{tabular}{|c|c|c|c|c|c|c|c|c|c|}
\hline \multirow{2}{*}{ Variables } & \multirow{2}{*}{$\begin{array}{c}\text { Measuring } \\
\text { Unit }\end{array}$} & \multicolumn{2}{|c|}{$\begin{array}{c}\text { Pre } \\
\text { measuring }\end{array}$} & \multicolumn{2}{|c|}{$\begin{array}{c}\text { Post } \\
\text { measuring }\end{array}$} & \multirow{2}{*}{$\begin{array}{l}\text { Difference } \\
\text { between } \\
\text { the two } \\
\text { averages }\end{array}$} & \multirow{2}{*}{$\begin{array}{l}\text { Improvement } \\
\text { rate }\end{array}$} & \multirow{2}{*}{$\begin{array}{l}\text { Value }(\mathrm{T}) \\
\text { Calculated }\end{array}$} & \multirow{2}{*}{$\begin{array}{l}\text { Level of } \\
\text { significance }\end{array}$} \\
\hline & & $S$ & $\pm \mathrm{E}$ & $S$ & $\pm \mathrm{E}$ & & & & \\
\hline $\begin{array}{l}\text { Ability of the } \\
\text { legs muscles }\end{array}$ & $\mathrm{Cm}$ & 33.20 & 0.75 & 38.21 & 0.25 & 5.01 & 13.11 & 3.33 & Indicated \\
\hline $\begin{array}{l}\text { Strength of } \\
\text { leg muscles }\end{array}$ & $\mathrm{Kg}$ & 55.25 & 0.63 & 62.36 & 0.32 & 7.11 & 11.40 & 3.24 & Indicated \\
\hline $\begin{array}{c}\text { Abdominal } \\
\text { muscle } \\
\text { capacity }\end{array}$ & No & 18.20 & 0.21 & 20.10 & 0.14 & 1.90 & 9.45 & 3.28 & Indicated \\
\hline $\begin{array}{c}\text { Strength of } \\
\text { abdominal } \\
\text { muscles }\end{array}$ & $\mathrm{Kg}$ & 38.51 & 0.52 & 40.32 & 0.63 & 1.81 & 4.48 & 3.65 & Indicated \\
\hline $\begin{array}{c}\text { Strength of } \\
\text { back muscles }\end{array}$ & $\mathrm{Kg}$ & 52.50 & 0.36 & 58.62 & 0.58 & 6.12 & 10.44 & 3.24 & Indicated \\
\hline $\begin{array}{c}\text { Muscle } \\
\text { capacity } \\
\text { Arms }\end{array}$ & No & 15.52 & 0.25 & 20.10 & 0.21 & 4.58 & 22.78 & 3.17 & Indicated \\
\hline $\begin{array}{c}\text { Strength of } \\
\text { arm muscles }\end{array}$ & M & 5.51 & 0.98 & 6.25 & 0.15 & 0.74 & 11.84 & 3.59 & Indicated \\
\hline $\begin{array}{c}\text { The strength } \\
\text { of the right } \\
\text { fist }\end{array}$ & $\mathrm{Kg}$ & 31.09 & 0.32 & 34.25 & 0.63 & 3.16 & 9.22 & 3.52 & Indicated \\
\hline $\begin{array}{l}\text { The strength } \\
\text { of the left fist }\end{array}$ & $\mathrm{Kg}$ & 28.95 & 0.28 & 33.21 & 0.35 & 13.99 & 42.12 & 3.21 & Indicated \\
\hline $\begin{array}{l}\text { Circumference } \\
\text { of arms }\end{array}$ & $\mathrm{Cm}$ & 19.22 & 0.85 & 20.98 & 0.11 & 1.76 & $9.15 \%$ & 3.10 & Indicated \\
\hline
\end{tabular}




\begin{tabular}{c|c|c|c|c|c|c|c|c|c}
\hline $\begin{array}{c}\text { Circumference } \\
\text { of the legs }\end{array}$ & $\mathrm{Cm}$ & 28.62 & 0.32 & 30.21 & 074 & 1.59 & $5.55 \%$ & 2.98 & Indicated \\
\hline \hline
\end{tabular}

Tabular value at a significant level of 0.05 and freedom degrees $9=2.26$

Table (4) shows statistically significant differences between the pre and post measurements of the control group in the functional variables tests for the benefit of the telemetry. The calculated value $(t)$ was greater than the tabular value at the significance level $(0.05)$

Table (5) The significance of the differences and the rates of improvement between the averages of the dimensional measurements in the experimental and control groups in the functional variables tests $\mathrm{N}=12$

\begin{tabular}{|c|c|c|c|c|c|c|c|}
\hline \multirow[t]{2}{*}{ Variables } & \multirow{2}{*}{$\begin{array}{l}\text { Measuring } \\
\text { Unit }\end{array}$} & \multicolumn{2}{|c|}{$\begin{array}{l}\text { Experimental } \\
\text { group }\end{array}$} & \multicolumn{2}{|c|}{$\begin{array}{l}\text { Control } \\
\text { group }\end{array}$} & \multirow{2}{*}{$\begin{array}{l}\text { Value }(\mathrm{T}( \\
\text { Calculated }\end{array}$} & \multirow{2}{*}{$\begin{array}{c}\text { Level of } \\
\text { significance }\end{array}$} \\
\hline & & $\mathrm{S}$ & $\pm \mathrm{E}$ & $\mathrm{S}$ & $\pm \mathrm{E}$ & & \\
\hline $\begin{array}{l}\text { Ability of the legs } \\
\text { muscles }\end{array}$ & $\mathrm{Cm}$ & ra,or & $\cdot, Y_{1}$ & rᄉ, r) & $\cdot$, ro & $r, 01$ & Indicated \\
\hline Strength of leg muscles & $\mathrm{Kg}$ & $T V, Y I$ & $\cdot, I V$ & TY,Y & $\cdot, r Y$ & $r, Y)$ & Indicated \\
\hline $\begin{array}{l}\text { Abdominal muscle } \\
\text { capacity }\end{array}$ & No & r Y,Or & דוr, & $r \cdot, l \cdot$ & $\cdot, 1 \leq$ & $r, r q$ & Indicated \\
\hline $\begin{array}{l}\text { Strength of abdominal } \\
\text { muscles }\end{array}$ & $\mathrm{Kg}$ & $\varepsilon 0, r\}$ & $\cdot, 0 Y$ & $\varepsilon \cdot, r$ & מד, - & r, « & Indicated \\
\hline Strength of back muscles & $\mathrm{Kg}$ & $T \leqslant, Y$. & $\cdot, r r$ & $0 \wedge, 7 Y$ & $\cdot, 01$ & r,r & Indicated \\
\hline Muscle capacity Arms & No & YY,YT & $\cdot, 1 \leq$ & $r \cdot, l \cdot$ & $\cdot, Y_{1}$ & $r, 1 \leq$ & Indicated \\
\hline Strength of arm muscles & $\mathrm{M}$ & $\wedge, Y_{1}$ & $\cdot, 0 Y$ & $7, Y 0$ & $\cdot, 10$ & r,OY & Indicated \\
\hline $\begin{array}{c}\text { The strength of the right } \\
\text { fist }\end{array}$ & $\mathrm{Kg}$ & rᄉ, r & $\cdot, \zeta \wedge$ & $\Gamma \leqslant, r_{0}$ & 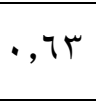 & r, r人 & Indicated \\
\hline $\begin{array}{l}\text { The strength of the left } \\
\text { fist }\end{array}$ & $\mathrm{Kg}$ & $r \div, 1$. & $\cdot, r T$ & ru, & • , r & $r, Y$ & Indicated \\
\hline Circumference of arms & $\mathrm{Cm}$ & TY,YY & $\cdot, r T$ & $r \cdot, 9 \Lambda$ & $\cdot, 11$ & $r, \leqslant 1$ & Indicated \\
\hline Circumference of the legs & $\mathrm{Cm}$ & 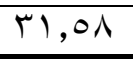 & $\cdot, 1 \leq$ & $r \cdot, r)$ & $\cdot V \varepsilon$ & r,Yo & Indicated \\
\hline
\end{tabular}

Value $(\mathrm{T})$ at significance level $(0.05)=1.85$

Table (5) shows that statistically significant differences were found between the pre measurements of the experimental and control groups in the functional and physical variables tests in favor of the telemetry. The calculated value $(\mathrm{t})$ was greater than the tabular value at the significance level (0.05)

\section{Discussion of results}

Table (3) shows statistically significant differences between the averages of the pre and post measurements of the experimental group in the functional variables tests for the benefit of the telemetry, where the calculated value $(\mathrm{t})$ was greater than the tabular value at the significance level (0.05) Experimental research.

The study shows that training by restricting venous blood flow causes statistically significant differences as an indicator of increased blood flow in the muscles, followed by an increase in the circumference of the thigh and arm muscles, as well as muscle mass and muscle strength,

While the same exercise without restriction of blood flow and muscle retention did not give This is consistent with the study of Matthew Matthews et al. (2012), Stobalen Christopher (2009), (12), Barry (2004) (9) on the effectiveness of KAATSU training in improving muscle strength. 
The results of some studies indicate that the low intensity exercises improved muscle strength while the same exercises with the same intensity without muscle restriction caused an improvement in the level of muscle strength where the strength of the muscles of the two men with the exercises of the group of the second group without exercises KAATSU The researcher attributed the results that improvement with an increase of space The change in the mass and the musculoskeletal area observed in the present study is a direct result of increased muscle inflation and strength. This is confirmed in the study of Bergomaster (2003), 10 for Loring (2003), Nader (2005)

In this regard, Madarame (2008) (22) agrees that the temperature resulting from partial vascular occlusion leads to a decrease in the amount of oxygen, which increases the rate of blood flow in skeletal muscles. In addition, the process of hypoxia works Stimulates blood vessels to secrete the growth factor of the muscles (VEGF) and the secretion of the fibroblast growth factor (FGF).

These factors are the most important in the growth of veins and muscle lupus, which leads to increased muscle strength and muscle hypertrophy.

The increase in muscle size is explained by the effect of training by restricting venous blood flow, as the performance of many aerobic training modules significantly stimulates the muscles of the body, although the boxer was expected to become more tired during blood flow restriction, which did not occur as in units

The results showed an increase in the electrical stimulation of the muscles that restrict the flow of venous blood compared to the same exercises without restricting the blood flow. The study showed that the intensity of the application of the program coincided with the restriction of flow of blood Venous affect positively on the increase in the thigh and arm circumference and increase muscle strength and capacity. (13) (18)

The results of the current study indicate that the KAATSU exercises (experimental group) have statistically significant differences in the increase of the upper and lower extremities accompanied by increased muscle strength, while the exercises without restriction of blood flow do not occur those differences with statistical indications (for the control group),

Which affected In addition to the other functional and physical variables, especially for the experimental group, which was supported by increased blood feeding of the working muscles and also helped in the regularity of breathing and delayed access to fatigue (20)

Both Fujita and S, et al. (2007) (12) note that both low and high intensity exercises restricting venous blood flow increase the size and mass of skeletal muscles more than only high-strength resistance training, It is assumed that training restricting blood flow will stimulate protein synthesis in muscles more than strength training only.

While the results of previous studies show that high intensity training with venous blood flow restriction better affects low intensity training while restricting venous blood flow to increase muscle hypertrophy, and confirms a positive relationship between occurrence of phosphorylation (S6K1) in the early hours after training High intensity and improved muscle mass after several weeks of high intensity training in humans (31) (11.)

Thus, the first hypothesis was achieved, which states that there are statistically significant differences between the averages of pre and post measurements at the level of some physical and functional variables in boxers experimental research group.

Table (4) shows statistically significant differences between the pre and post measurements 
of the control group in the biological variables tests for the benefit of the telemetry. The calculated value $(\mathrm{t})$ is greater than the tabular value at the significance level $(0.05)$ on boxers.

Abdul Rahman Saif (2010) states that a good boxer knows how to pay within his abilities so that he can benefit from the different possibilities that characterize him. He must develop his preferred movements so that his performance is more effective and the boxer who enjoys high physical preparation has good skill performance. : 17)

Thus, the second hypothesis was achieved, which states that there are statistically significant differences between the averages of pre and post measurements at the level of some functional and physical variables in boxers. The control group

Table (5) shows that statistically significant differences were found between the pre measurements of the experimental and control groups in the tests of functional and physical variables for the benefit of the telemetry. The value of $(\mathrm{t})$ was greater than the tabular value at the significance level (0.05)

Training that increases and amplifies skeletal muscle, which is described as the maximum peak of the strength and speed curve, is defined as the percentage of the peak of the power curve, which depends on the age and duration of the training module and ultimately leads to the adaptation of the required exercise (14.)

Strength training (1RM) is the most influential factor in training modules and overall neurological responses, which can be traced after 10 training modules (17), representing the most powerful strength and resistance exercises on body components and skeletal muscle growth in adult men (33)

Thus, the third hypothesis was achieved, which states that there are statistically significant differences between the two dimensions of the measures of the two dimensions in the experimental and control groups at the level of some physical and functional variables in boxers.

\section{Conclusion:}

-Promoter training helps to increase muscle tone and increase muscular strength in boxers. -Promoter training helps to increase the muscle strength of boxers

Recommendations:

-Educating boxing trainers to effectively use the training of boxers for boxers because of their positive impact on increasing the level of muscle circumference and increase the muscle strength of boxers.

-Conduct further research on the use of drills in different sports. 


\section{References}

1-Abdul Rahman Saif (2010): biochemical changes for continuous and training of the boxers, the knowledge facility, Alexandria

2-Abdel Fattah Fathi Khader, Mohamed Talaat Ibrahim, Abdel Rahman Saif, Hamdi AbdelMaksoud El-Jazzar (2005): Boxing, Part I, Faculty of Physical Education for Boys in Abu Qir, Alexandria.

3-Mr. Ismail Al-Hawi (2006): Boxing Fundamentals of Practical Applications Theory, Arab Publishing Center, Zagazig

4- Abe, T: Effects of short -term low intensity Kaatsu training on strength and skeletal muscle size in young men (Japanese with English abstract). J Training SciExerc Sport 16: 199-5

5- AiliangXie, James B. Skatrud, Steven R. Barczi , Kevin Reichmuth, Barbara J. Morgan , Sara Mont, Jerome A. Dempsey: Influence of cerebral blood flow on breathing stability, Journal of Applied Physiology Published 1 March 2009Vol. 106no. 850856DOI: 10.1152/japplphysiol.90914. (2009).

6- Aymanfekry :Relation between prostaglandin changes as an indicator for blood flow at muscles during high intensity effort, research not published for master degree, faculty of physical education for boys, Helwan University, (2006)

7- Barry, P. M.; Yang, H. and Ronald, L.: What makes vessels grow with exercise training? J Applied Physiology 97: 1119-1128, (2004).

8- Burgomaster KA, Moore DR, Schofield LM, Phillips SM, Sale DG, and Gibala MJ. Resistance training with vascular occlusion: metabolic adaptations in human muscle. Med Sci Sports Exerc 35: 1203-1208,( 2003).

9-Campos GER, Luecke TJ, Wendeln HK, Toma K, Hagerman FC, Murray TF, Ragg KE, Ratamess NA, Kraemer WJ, and Staron RS: Muscular adaptation in response to three different resistance-training regimens: specificity of repetition maximum training zones. Eur J ApplPhysiol 88: 50-60, (2002).

10- Christopher S. Fry, Erin L. Glynn, Micah J. Drummond, Kyle L. Timmerman, Satoshi Fujita , Takashi Abe, ShaheenDhanani, Elena Volpi , Blake B. Rasmussen: Blood flow restriction exercise stimulates mTORC1 signaling and muscle protein synthesis in older men. Journal of Applied Physiology: 10.1152/japplphysiol.01266.(2009)Published 1 May Vol. 108no. 1199-1209DOI, (2009).

11- DURJASZ, D.; NOWAK, T., (2007): Boxer in den 90er Jared -Veranda unguent am Kamp filed Sport wacky now, 34 (1/2), 10-12. (Abstract auf detach in Spoilt).

12- Fujita S, Abe T, Drummond MJ, Cadenas JC, Dreyer HC, Sato Y, Volpi E, and Rasmussen BB: Blood flow restriction during low-intensity resistance exercise increase SGK1 phosphorylation and muscle protein synthesis. J Applied Physiology 103: 903910. (2007).

13- Gable D. ; coaching wrestling successfully I , ed , Human Kineticics , USA , 2009

14- Glass DJ. Skeletal muscle hypertrophy and atrophy signaling pathways. Int J Biochem Cell Biol 37, (2005).

15-Goto K, Ishii N, Kizuka T, Takamatsu K. , The impact of metabolic stress on hormonal responses and muscular adaptations. Med Sci Sports Exerc 37: 955-963, (2005) 
16- Ismail Hamed Othman, Mohamed Abdel Aziz Ghoneim, Zia El Din Mohamed El Azab, Atef Magaghory Shaalan (2005): Boxing Education, Management and Training, 3, Cairo.

17- Kraemer RR, Kilgore jl, Kraemer GR: CastranceVD Growth hormone, IGF-1, and testosterone responses to resistive exercise. Med Sci Sports Exerc 24: 1346-1352, (1991).

18- Kraemer wj. Ratamess NA: Fundamentals of resistance training progression and exercise prescription. Med Sci Sports Exerc 36: 674-688, (2004).

19- L. Holm , S. Reitelseder, T. G. Pedersen , S. Doessing , S. G. Petersen, A. Flyvbjerg , J. L. Andersen, P. Aagaard, M. Kjaer:Changes in muscle size and MHC composition in response to resistance exercise with heavy and light loading intensity.Journal of Applied PhysiologyPublished, 1 November 2008Vol. 105no. 1454-1461DOI: 10.1152/ japplphysio 1.90538.2008

20- LoringB ,Rowell: Ideas about control of skeletal and cardiac muscle blood flow: cycles of revision and new vision, Department of Physiology and Biophysics, University of Washington School of Medicine, Seattle, Washington 98195,(2003).

21- Madarame H, Neya M, Ochi E, Nakazato K, Sato Y, Ishii N. Cross transfe: Effects of resistance training with blood flow restriction. Med Sci Sports Exerc 40: 258-263, (2008).

22- Matthew P. Harber, Adam R. Konopka, Miranda K. Undem, James M. Hinkley, KirilMinchev, Leonard A. Kaminsky, Todd A. Trappe, Scott Trappe: Aerobic exercise training induces skeletal muscle hypertrophy and age-dependent adaptations in myofiber function in young and older men. Journal of Applied PhysiologyPublished, 1 November 2012Vol. 113no. 1495-1504DOI: 10.1152/japplphysiol.00786, (2012).

23- McDonagh MJ and Davies CT: Adaptive response of mammalian skeletal muscle to exercise with high loads. Eur J ApplPhysiol 52: 139-155, (2002).

24- Nader GA. :Molecular determinants of skeletal muscle mass: getting the "AKT" together. Int J Biochem Cell Biol Oct;37 (10):1985-96. Epub Mar, 21,( 2005).

25-Peter H. Connolly, Vincent J. Caiozzo, FrankZaldivar, Dan Nemet, Jennifer Larson, Shepin Hung, J. Denis Heck, G. Wesley Hatfield, Dan M. Cooper: Effects of exercise on gene expression in human peripheral blood mononuclear cells, Journal of Applied Physiology Published 1 October 2004Vol. 97no. 1461-1469DOI: 10.1152/japplphysiol.00316, (2004).

26- Radwa Soliman Elsharkawy, Maysa Mohamed Rabia Effect of training program with restricted venous blood flow "KAATSU"' on skeletal muscle (mass and size), strength, Prostaglandins (PGE2) and $400 \mathrm{~m}$ sprinting records, International Journal of Sports Science Faculty of Physical Education for Boys Kir Alexandria

27- Rowell LB, Freund PR, and Hobbs SF: Cardiovascular responses to muscle ischemia in humans' ApplPhysiol,Circ Res 48: 137-147,( 2009).

28-Sami Muheb Hafez (2005): the entrance to modern boxing, I 2, library tree Aldr Mansoura.

29- Shinohara M, Kouzaki M, Yoshihisa T and Fukunaga T: Efficacy of tourniquet ischemia for strength training with low resistance. Eur J Applied Physiology OccupPhysiol 77, (1998).

30-Stephen D. Patterson, Richard. A. Ferguson: Increase in calf post-occlusive blood flow and strength following short-term resistance exercise training with blood flow 
restriction in young women, European Journal of Applied Physiology, March 2010, Volume 108, Issue 5, pp 1025-1033,(2010).

31-Takarada Y, Takazawa H, Sato Y, Takenoshita S, Tanaka Y, and Ishii N. Effects of resistance exercise combined with moderate vascular occlusion on muscular function in humans. J ApplPhysiol 88: 2097-2106,( 2009).

32- Takarada $\mathrm{Y}$, Sato $\mathrm{Y}$, and Ishii $\mathrm{N}$ : Effects of resistance exercise combined with vascular occlusion on muscle function in athletes. Eur J ApplPhysiol 86: 308-314, (2002).

33- Takashi Abe1, Charles F. Kearns1, and Yoshiaki Sato: Muscle size and strength are increased following walk training with restricted venous blood flow from the leg muscle, Kaatsu-walk training, Journal of Applied Physiology vol. 100 no. 5 14601466 Article,10.1152/japplphysiol.01267.2005,1 May (2006).

34-Yasuda T, Abe T, Sato Y, Midorikawa T, Kearns CF, Inoue K, Ryushi T, and Ishii N: Muscle fiber cross-sectional area is increased after two weeks of twice daily Kaatsuresistance training. Int J Kaatsu Training Res 1: 65-70, (2008). 